\title{
非典型溶血性尿毒症症候群（aHUS）
}

宮川義隆*

\section{Current review of aHUS}

Yoshitaka MIYAKAWA

要約 : 非典型溶血性尿毒症症候群 (aHUS) は, 補体が異常に活性化して発症する血栓性微小血管障害症 (TMA) である，非免疫性の溶血性貧血，血小板減少，腎不全を特徵とする。1970 年代に補体 C3 が低下する溶血性 尿毒症症候群(HUS)の一種と報告され，1990 年代は血栓性血小板減少性紫斑病(TTP)の亜型と見なされてい た。 小児に多いHUS の 9 割が自然軽快するのに対し, aHUS は血漿交換療法を行っても発症から 1 年後には 約 2 割が死亡, 約 5 割が慢性腎不全に至る難治性疾患として知られていた. 2000 年代に aHUS の病態解明が 進み，複数の補体制御因子に遺伝子異常があることが判明した。さらに，aHUS に対する初めての治療薬と して補体 C5に対する抗体医薬エクリズマブが承認され，治療法が大きく進歩した。aHUS は希少疾病であ るが故に，医療者の経験と情報が不足しており，医療現場では TTP と aHUS との鑑別診断に苦慮することも 多い，本稿では aHUS の診断と治療について，最新の知見をもとに解説する.

Key words: aHUS, ecluizumab, TMA, complements

\section{1.はじめに}

約 10 年前まで血栓性血小板減少性紫斑病 (TTP), 溶血性尿毒症症候群 (HUS) と非典型溶血性尿毒症症 候群 (aHUS) は，血栓性微小血管障害症 (TMA) とい う共通の病理組織像をもつことから, TTP/HUS と いうひとつの疾患群として扱われていた。 2000 年代 初めに, TTP の原因が ADAMTS13 酵素欠損と解明 された1)。さらに, aHUS の病因として次々と補体制 御因子の遺伝子変異が発見された ${ }^{1,2)}$. TTP の治療は 血漿交換療法に加え，免疫抑制療法として副腎皮質 ステロイド，海外では抗体医薬リツキシマブが広く 使われている ${ }^{3-6)}$ 。一方, aHUSの治療はTTPに準 じて血漿交換療法が行われていたが効果にそしく, 約 20\%が死亡, 約 50\%が末期の腎不全に至り血液 透析を導入していだ)。補体 C5 に対する抗体医薬 エクリズマブが，2011 年に米国と欧州，2013 年に

\footnotetext{
*責任者連絡先：

埼玉医科大学総合診療内科

干 350-0495 埼玉県入間郡毛吕山町毛吕本郷 38

Tel: 049-276-1111, Fax: 049-276-1667

E-mail: miyakawa@saitama-med.ac.jp
}

本邦で aHUS に承認されほほぼ全ての患者が血漿交 換療法から離脱し，TMAの再燃防止，さらに一部 の患者は血液透析から離脱できるようなった。病態 の解明と新規治療が臨床の現場に導入されてから日 が浅く, aHUS の臨床的診断が TMAのうち, TTP と HUS の除外診断によることから診断に苦慮する 場面が多いと推測される。国内外の知見をもとに， 適切な診断とエクリズマブの適正使用について解説 を行う。

\section{2. 疫学}

国内の正確な患者数は不明である。欧州における 発症頻度が 100 万人に約 2 人であることから ${ }^{8,9)}$, 国内の患者数は約 200 名と推定される．TTP 患者の 約半数, HUS 患者の約 $10 \%$ に相当する，患者に性 差はなく，発症年齢は小児から成人まで幅広い。な お，補体制御因子の遺伝子異常を約 $50 \%$ に認める が，遺伝子異常をもつ個体の約 $30 \%$ の発症する ことから, 遺伝子の複合異常または感染症などの環 境因子が発症に必要と考えられている ${ }^{1,9,10)}$. 


\section{3. 症状}

溶血性貧血による息切れと黄疸に加えて，血小板 減少による紫斑などの出血症状を認めることがあ る。病原性大腸菌感染による HUS と異なり, aHUS には原則として血便を認めない。急性腎不全による 浮腫, 管理が難しい高血圧症, 乏尿は特徵的で, 血 液透析が必要になることが多い。 なお, 頭痛, 意識 変容, 呼吸器症状, 下痢症, 腹痛などを伴うことも あり, 症状のみで aHUS を TTP と HUS と明確に鑑 別するのが難しいことがある ${ }^{6,11,12) . ~}$

\section{4. 診断}

臨床的には, 非免疫性溶血性貧血, 血小板減少, 腎不全の三徵候が必要である ${ }^{6,10,12)}$ (図 1)。非免疫 性溶血性貧血の診断には，クームス試験が陰性であ ること, 間接ビリルビン優位の黄疸, $\mathrm{LDH}$ 高值,
血清ハプトグロビン低值が必要である。また，全例 ではないが，破砕赤血球を認めることが多い。播種 性血管内凝固症候群 (DIC) は APTT と PT が延長し, 血清フィブリノーゲンが低下することから, aHUS と鑑別することができる.

TMA のうち, 症状が似ている TTP, HUS と aHUS の鑑別診断には注意が必要である1)。主に小児で, 病原性大腸菌に污染された可能性のある肉を食べ, 血便と急性腎不全のある患者であれば HUS が強く 疑われる，便培養検査で志賀毒素を産生する病原性 大腸菌，便中の志賀毒素を簡易キットで検出，ある いは血清中の LPS-IgM 抗体を検出することにより HUS と診断することができる，患者の周辺に同じ 食べ物を口にして，血便，血球減少，急性腎不全の 患者がいないか問診をすることも重要である。

TTP は溶血性貧血, 血小板減少に加えて, 発熱, 腎障害, 動摇する神経症状が古典的な診断法であっ たが，最近では ADAMTS13 活性の測定が保険適応

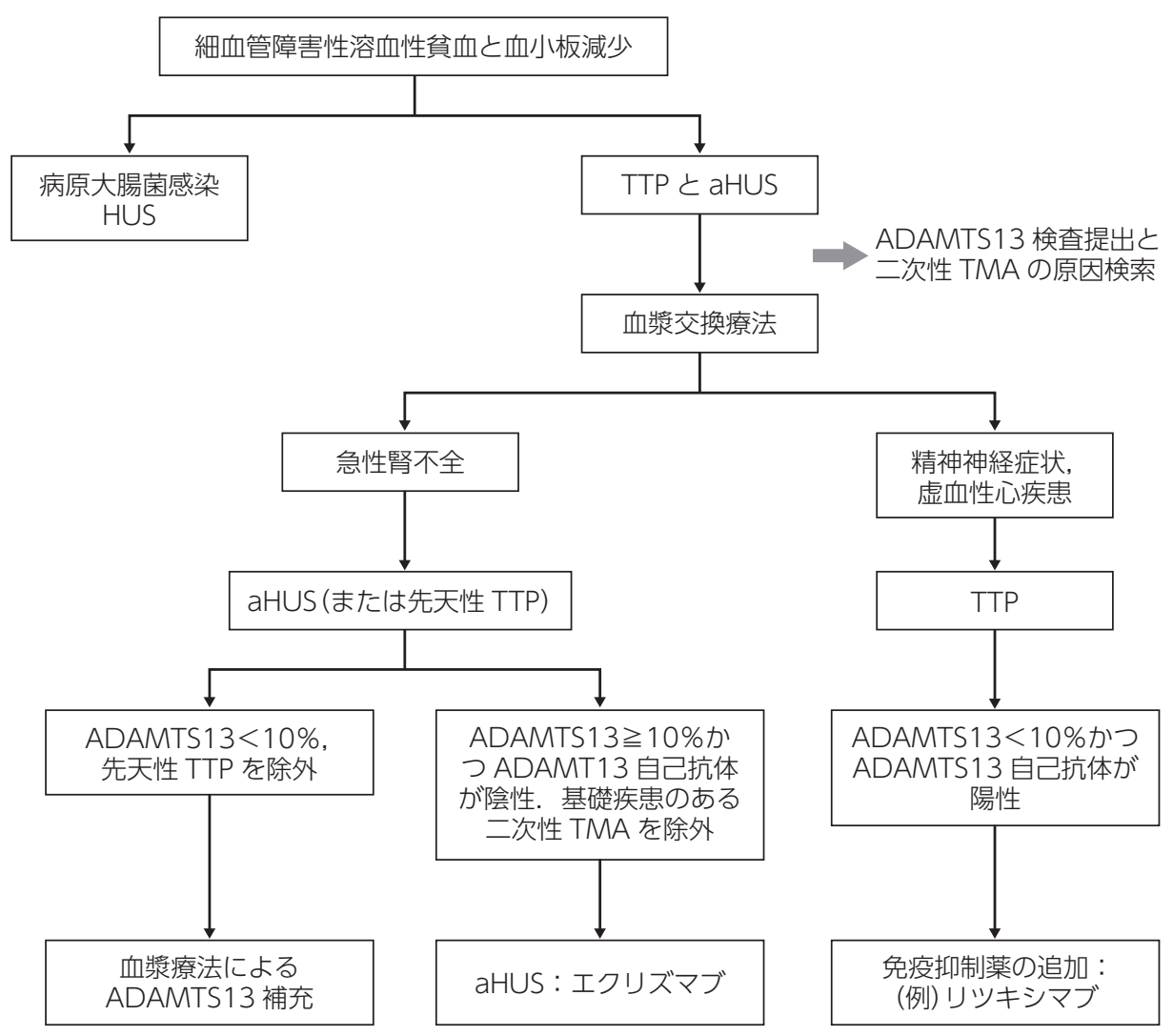

図 1 TTP, HUS と aHUS の鑑別診断と治療(文献 6 を一部改変)

TMA：血栓性微小血管障害症，リツキシマブは保険適応外(国内). 


\section{TTP と aHUS の鑑別診断に有用な ADAMTS13 検査}

国内では対外診断薬として未承認であるが, ADAMTS13 検査は TTP と aHUS の鑑別診断に有用 である ${ }^{11)}$ ，血漿交換療法を開始する前の検体で, ADAMTS13 活性 <5\%（海外では $<10 \%$ とする場合 がある)であればTTP と診断する(図 1)。TTPのう ち, ADAMTS13 インヒビターが陽性であれば後天 性 TTP である。同インヒビターが陰性であれば, 先天性 TTP 念頭に家族歴をよく聴取する。なお, インヒビターが陰性であっても家族歴がない場合, ADAMTS13 活性を抑制しない自己抗体が存在する 可能性を否定できない.

aHUS の ADAMTS13 活性は正常，または 30〜40\% と軽度低下することが多い, ${ }^{6,10)}$ 。なお，悪性高血圧, 膠原病, 臓器移植関連 TMA においてもADAMTS13 活性が軽度低下することから，鑑別診断においては 留意する。フランスの TMA センターが 160 名の TMA 患者を調べ，血清クレアチニンが $2.2 \mathrm{mg} / \mathrm{dL}$ 以 下, 血小板数が 3 万 $/ \mu \mathrm{L}$ 以下, 抗核抗体が陽性の場 合, ADAMTS13 活性が $5 \%$ 以下に低下したTTPで ある可能性が高いことを報告している(表 3) ${ }^{17)}$. 自 施設でADAMTS13 活性を測定できる医療機関は極 めて限られており, 外注検査の結果が判明するまで 数日かかる現状では，TTP と aHUS を鑑別するのに 有用な情報と考えられる。

\section{7. 補体経路と aHUS の病態}

aHUS においては, 補体経路の異常活性化により 血管内皮が損傷され，細血管において血栓症を起こ $す^{8)}$. aHUS の約 $50 \%$ に補体制御因子の遺伝子变異, または H 因子に対する自己抗体を認める。補体の 活性経路は凝固系のように複雑で，3つの経路があ る(図 2). 古典的経路は抗原抗体反応, レクチン経 路は細菌表面にある糖鎖抗原が刺激になり, 補体 C4 以下のカスケードが活性化される。 aHUSにおいて は，代替経路のみが異常に活性化されるため C4 が 低下せず，C3 のみ減少するのが特徵である $(\text { 図 2 })^{8)}$. いずれの経路も最終的に, C $5 b$ と C6〜C9 から成る $\mathrm{MAC}$ を活性化させる. MAC は細菌と細胞の膜に
表 3 各検査值と ADAMTS13 欠損の関連性

\begin{tabular}{lccc}
\hline & 補正 Odds 比 & $95 \%$ 信頼区間 & $\mathrm{P}$ 值 \\
\hline $\begin{array}{l}\text { 血清クレアチニン } \\
\leq 2.26 \mathrm{mg} / \mathrm{dL}\end{array}$ & 23.4 & $8.8-62.5$ & $<.001$ \\
血小板数 $\leq 3$ 万 $/ \mu \mathrm{L}$ & 9.1 & $3.4-24.2$ & $<.001$ \\
抗核抗体陽性 & 2.8 & $1.0-8.0$ & $<.05$ \\
\hline
\end{tabular}

穴をあけて傷害する強い作用をもつ、AHUSにおい ては補体経路の異常活性化により生じた MACが細 血管の内皮細胞を傷つけることにより血栓症をきた し, 様々な臓器の虚血症状につながる。

補体が異常に活性化すれば臓器障害, 反対に活性 が低下すれば免疫力の低下につながる。このため, 補体経路の恒常性を維持するため活性化または抑制 する複数の制御因子がある。自動車でいえば, アク セルとブレーキの関係に相当する。 aHUSにおいて は，抑制因子である $\mathrm{H}$ 因子， I 因子， MCP，トロン ボモジュリンの遺伝子変異と, 活性化因子の B 因 子と C3 の機能獲得型の遺伝子変異が報告されてい る(図 2 $)^{1,10)}$ 。 なお, aHUS の約 1 割は, H 因子に対 する自己抗体が原因で発症する ${ }^{1,10)}$.

aHUS 研究の第一人者であるイタリアの Marina Noris は, 273 名の aHUS 患者の遺伝子解析を行っ た ${ }^{18)}$. 内訳は, 家族性 82 名, 孤発例 191 名である. 全体の約半数に遺伝子異常を認めた (表 4 ${ }^{18)}$. この うち, 死亡または腎不全への移行率が高い $\mathrm{H}$ 因子 異常は $24 \%$, I 因子異常は 4\%であった ${ }^{18)}$. 一方, 予後が良好な $\mathrm{MCP}$ 異常は 7\%, H 因子自己抗体が 陽性の患者は $3 \%$ であった ${ }^{18)}$ ，このような遺伝子解 析の結果は解析を行う対象集団により異なることが 多く, 本邦では海外と異なり $\mathrm{C} 3$ 変異が多い2).

\section{8. 古典的治療}

aHUS に対する治療は過去 20 年間にわたり, TTP に準じた血漿交換療法が中心であっだ7。予後が良 好な $\mathrm{MCP}$ 異常と H 因子自己抗体の症例では, 血漿 交換療法で寛解するが，H因子变異を含む他の aHUS 症例は血漿交換療法が無効で死亡または，末 期の腎不全に移行していた ${ }^{7,16)}$. 2009 年の英国 aHUS 


\section{Classical}
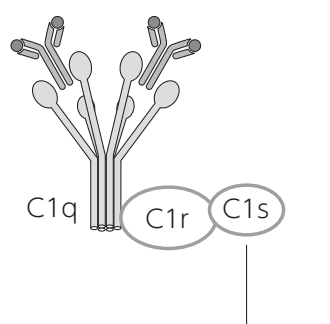

Lectin

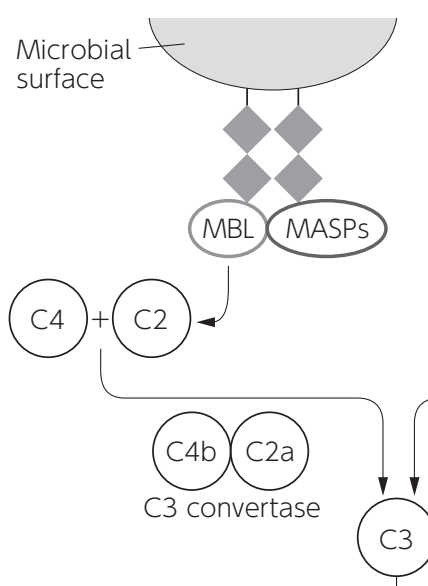

C3
Alternative

C3 tick-over

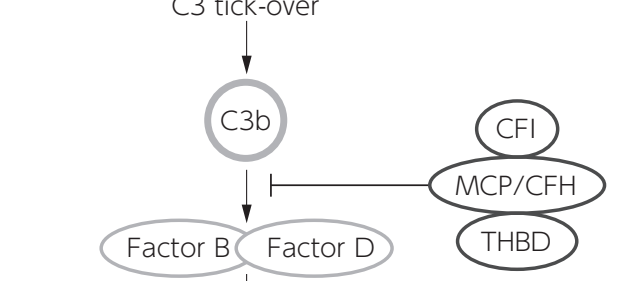

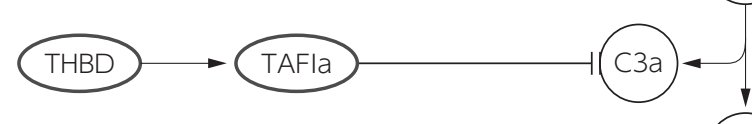
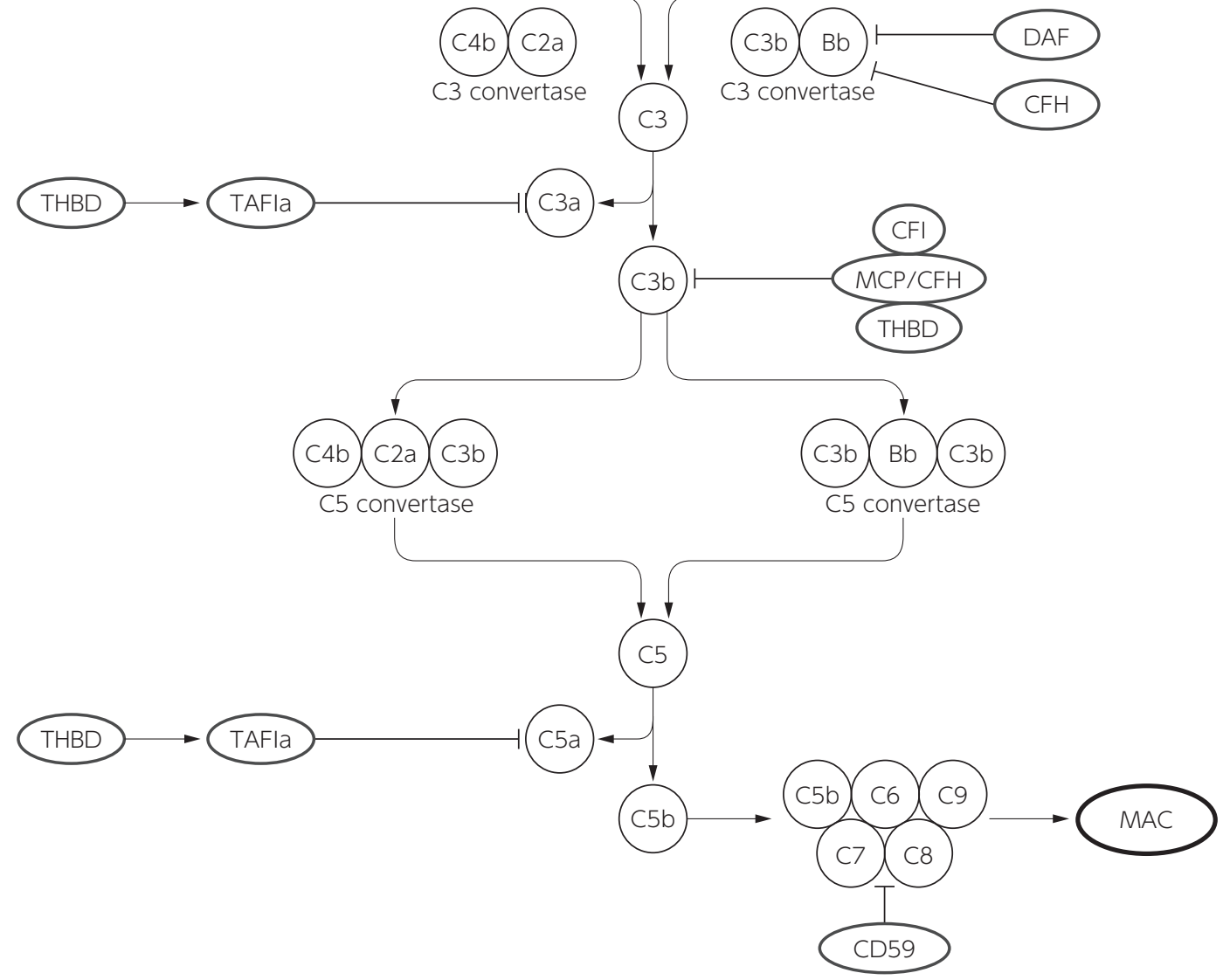

C5 convertase

(

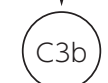

図 2 補体経路の活性化経路と補体制御因子の関係(文献 9)

$\mathrm{CFH}$, factor H; CFI, factor I; DAF, decay accelerating factor; MAC, membrane attack complex; MASP, mannan-binding lectin serine protease; MBL, mannose-binding lectin; MCP, membrane cofactor protein; TAFIa, thrombin-activatable fibrinolysis inhibitor; THBD, thrombomodulin.

\section{表 4 aHUS の補体異常}

\begin{tabular}{|c|c|c|c|c|c|c|c|c|c|}
\hline \multirow[b]{2}{*}{$\begin{array}{c}\text { 被験者数 } \\
\text { (名) }\end{array}$} & \multicolumn{7}{|c|}{ 遺伝子変異 } & \multirow[b]{2}{*}{ CFH 抗体 } & \multirow[b]{2}{*}{ 合計 } \\
\hline & $\mathrm{CFH}$ & CFI & $\mathrm{C} 3$ & THBD & $\mathrm{MCP}$ & 複合異常 & $\begin{array}{l}\text { その他 (CFB, } \\
\text { C1-inh, CFP) }\end{array}$ & & \\
\hline 273 & $65(24 \%)$ & $10(4 \%)$ & $12(4 \%)$ & $13(5 \%)$ & $18(7 \%)$ & $9(3 \%)$ & $4(2 \%)$ & $8(3 \%)$ & $139(51 \%)$ \\
\hline
\end{tabular}


ガイドラインでは，血漿療法(血漿交換または血漿 輸注)が推奨されていた7)。なお，同ガイドラインに おいて，H因子と I 因子変異がある場合，腎移植は TMA 再燃により移植腎を衰失することから推奨さ れていない7)。さらに，MCP 異常または H 因子自己 抗体陽性例の腎移植の成績がよいことが示されてい だ．なお，同年イタリアの研究グループから， H 因子または I 因子異常による aHUS に対する肝臓と 腎蔵の同時移植に関するガイドラインが発表されて いる19)，腎移植のみでは TMA が再燃するため，H 因子と I 因子を産生する肝臓を同時に移植して TMA 再燃を予防する取り組みである ${ }^{19)}$ 。当初，成功例が 報告されたが，手術のリスクが高く，現在ではエク リズマブ投与により腎移植後の拒絶を予防できるよ うになり，肝腎同時移植を行うことはない ${ }^{10)}$.

\section{9. 初期治療}

過去に aHUS と診断されている患者の再燃であれ ば，エクリズマブから始めてもよいが，初発の場合

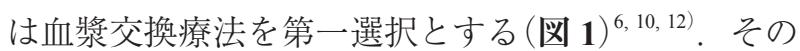
理由はADAMTS13 検査の結果が届くまで 3 5 日 かかること，血漿交換療法を数日行い，血小板減少 と溶血性貧血が著明に改善するのであれば臨床的に TTP と考えられ，血漿交換療法を継続すればよいと される ${ }^{6,10,12)}$. 反対に血漿交換療法を 5 日継続しても TMA が改善せず，急性腎不全が急速に進行して血 液透析が導入される場合は aHUS の可能性が高 $w^{6,10,12)}$. 理論的には腎臓の糸球体が不可逆的に損傷 される前にエクリズマブを開始して臓器保護を行い たいところであるが，TTP と aHUS の鑑別診断のた めには, ADAMTS13 検査結果が非常に参考になる こと, 後天性 TTPには免疫抑制療法, aHUS にはエ クリズマブと両者の治療法が異なるため, 初発の場 合は血漿交換療法を数日行ってから, 次の治療を慎 重に検討することが海外でも推奨されている ${ }^{6,10,12)}$.

\section{0. エクリズマブによる治療}

エクリズマブは C5 に対する完全ヒト型化抗体で ある(図 3)。体重 $40 \mathrm{~kg}$ 以上の成人 aHUS 患者では, 1 回 $900 \mathrm{mg}$ を週 1 回, 4 週間点滴静注する. 5 週目
から維持量 $1200 \mathrm{mg}$ を隔週で投与する。体重 $40 \mathrm{~kg}$ 未満であれば添付文書を参考に，用量を調整する。 エクリズマブ投与前に, 髄膜炎菌ワクチン (保険適 応外)の接種を行う。同ワクチンの事前接種が間に 合わない場合，髄膜炎菌の感染症を予防するため抗 菌薬を投与する.

Legendre らが N Engl J Med 誌に 2013 年に発表し た論文は，2つの第 II 相試験(37 名) から成る ${ }^{20)}$. C08-002 試験は血漿療法が無効な 12 歳以上の aHUS 患者(17名)を対象にした。エクリズマブ治療の開 始 26 週間後に，開始前と比べて血小板が 7.3 万 $/ \mu \mathrm{L}$ 増加した $\left(\right.$ 図 4 ${ }^{20)}$. 血小板数の回復は早く, 被験者 の約半数は 1 週間以内に血小板数が正常化し, 治療 開始 26 週間後には $87 \%$ が正常化した ${ }^{20)}$ 。なお，血 小板数の速やかな回復に比べてゆるやかであるが, eGFR も時間依存的に改善した (図 5 $)^{20)}$. 透析を必 要とした患者 5 名のうち 4 名 $(80 \%)$ が透析を離脱し ており ${ }^{20)}$ ，腎機能回復の観点から少なくとも半年間 の治療継続が望ましい.C08-003 試験は血漿交換に 依存性の被験者 (20 名)を対象に行い, 観察期間 (26 週）中, $80 \%$ の患者が TMA イベントフリー（25\%以 上の血小板減少, 血漿療法と透析開始なし) を達成 した ${ }^{20)}$ 。また，両試験において被験者の QOL の改 善を認め, 約 60 週 (中央值)の治療期間中に死亡と 重篤な有害事象を認めなかった ${ }^{20)}$ 。なお，被験者の 約 7 割に補体制御因子の遺伝子変異を認めたが, エ クリズマブの有効性との関連はなかった ${ }^{20)}$.

\section{1. エクリズマブの効果発現までの時間}

エクリズマブ開始 1 週間で約半数の症例におい て，血小板数は正常化する ${ }^{20)}$. 溶血の抑制と貧血の 改善も数週間以内に観察され, 血球の回復は速やか である。一方, 腎機能障害の回復には, 数力月を要 することが多い6,12,20). 海外第 II 相試験のデー夕に あるように半年かけて徐々に腎機能は回復するの で, 血球の回復が認められる場合, 少なくとも半年 間は治療を継続するのが望ましい。海外では長期投 与試験のデータが学会発表されており，2 年間継続 投与した場合でも，eGFRが徐々に回復することが 報告されている。 


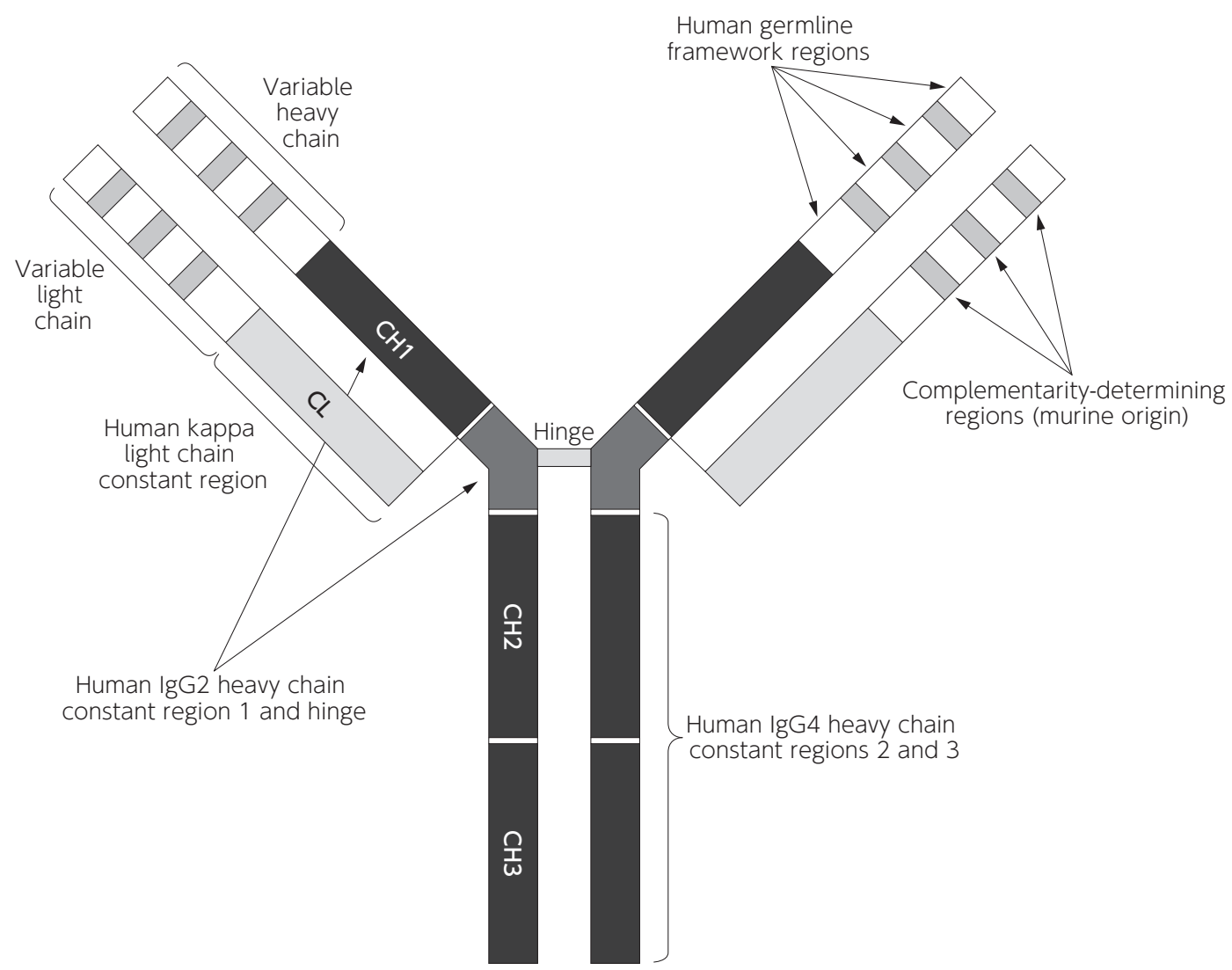

図 3 抗体医薬エクリズマブの構造

\section{2. エクリズマブが無効な場合}

aHUS の発症から時間が経過して不可逆的に腎臓 が障害された場合，エクリズマブの効果による腎機 能回復が期待できないことがある。一方，急性期の aHUS において，エクリズマブを 6〜8 週間投与して も溶血性貧血と血小板減少が回復しない場合, aHUS の診断が正しいか再確認することが望ましい'12)。補 体制御因子の遺伝子異常は約半数にしか認めない. このため, 仮に遺伝性検査をして陰性であっても aHUS を除外することができないので，臨床的な判 断が必要である。なお, diacylglycerol kinase epsilon (DGKE) 変異でもaHUS と同じ臨床像を示すが, こ の場合は補体系に異常がないので, エクリズマブは 無効である6,12).

\section{3. エクリズマブを中止できるか?}

aHUS に対するエクリズマブの治療効果は高い

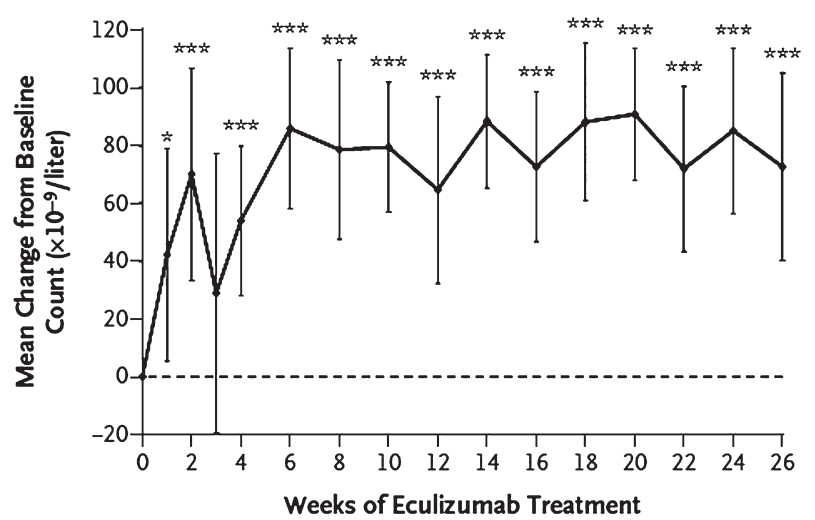

$\begin{array}{lllllllllllllll}\text { No. of } & 17 & 16 & 14 & 16 & 16 & 15 & 15 & 14 & 15 & 15 & 15 & 15 & 14 & 15\end{array}$ Patients

図 4 aHUS 患者に対するエクリズマブの第 II 相臨床試験 (海外 C08-002 試験)（文献 20)

4 回以上の血漿療法が無効な aHUS 患者(12 歳以上) 17 名 が対象. エクリズマブ投与 1 週間後に， $53 \%$ の患者の血 小板数が正常化した。治療開始 26 週後に，87\%の患者の 血小板数は正常であった。

が，年間の薬剤費が約 6,000 万円(成人の場合) と極 めて高額であること，免疫力低下による感染症合併 


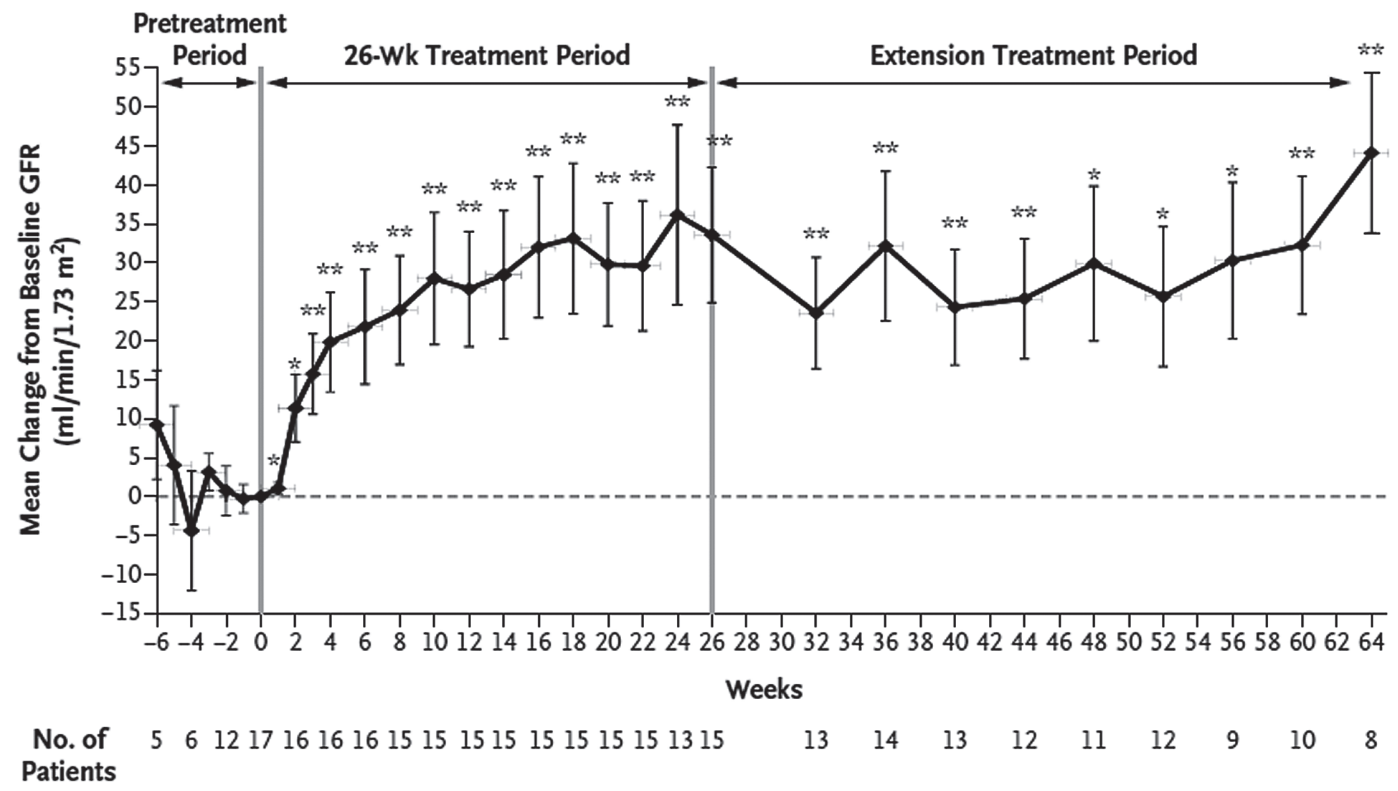

図 5 aHUS 患者に対するエクリズマブの第 II 相臨床試験(海外 C08-002 試験) (文献 20) エクリズマブ治療開始 26 週後に, eGFRは $32 \mathrm{~mL} / \mathrm{min} / 1.73 \mathrm{~m}^{2}$ 改善した。なお, 5 名中 4 名 $(80 \%)$ が 透析から離脱した。

懸念があること，さらに点滴のために長期にわたり 隔週で通院することは患者の QOL を低下させるこ ともあり，海外ではエクリズマブを安全に中止でき るか研究が進められている。

Legendre の第 II 相試験と後ろ向き試験のうち, エクリズマブを中止した 18 名中 5 名 $(27 \%)$ にMA が再燃した ${ }^{20)}$ 。さらに，Ardissino らはエクリズマブ で寛解に到達した aHUS 患者のうち, 同治療の中止 について同意を得られた被験者 10 名について，自 宅において簡易尿検査で潜血の有無を確認する方法 で慎重に経過を観察した ${ }^{21)}$ 。その結果，6 週間以内 に3 名 $(33 \%)$ が再発したが，治療再開により完全に 病勢を抑えられたことを報告した ${ }^{21)}$ 。言い方を変え れば，エクリズマブを中止しても約 $70 \%$ は再燃が ないことになる。現時点で安全にエクリズマブを中 止できる方法は確立していないが，予後が良好な MCP 異常と H 因子に対する自己抗体陽性例ではエ クリズマブを中止できる可能性がある ${ }^{6,11,12)}$ 。また, 再燃を早期に検出できるバイオマーカーが開発され れば，他の遺伝子変異による症例でもエクリズマブ を中止できる可能性が将来的に出てくる.

\section{4. 免疫抑制療法}

$\mathrm{H}$ 因子自己抗体の症例においては，血漿交換療法 に免疫抑制療法を組み合わせればaHUS を管理でき る可能性が高い ${ }^{10,12)}$ ，すなわち，自己免疫疾患であ るので，副腎皮質ステロイド，アザチオプリン，シ クロホスファミド，リツキシマブの有効性が報告さ れている ${ }^{12)}$ ，もともと予後が良好な $\mathrm{H}$ 因子自己抗 体群においては，エクリズマブを選択しない余地が あると考えられる。

\section{5. まとめ}

aHUS は長い間，TTP またはHUS の亜型として 扱われてきた。エクリズマブの登場により，aHUS がTTP と HUS と異なる疾患であることが再認識さ れるようになった。また， aHUS の治療法が従来の 血漿交換療法から分子標的治療に変化したのも特筆 すべきことである。 aHUS の診断は TTP, HUS と基 礎疾患をもつ TMAの除外診断によるため, 今後は 補体の活性化異常を検出して aHUS を確定診断でき るバイオマーカーの開発が望まれる。 
著者の利益相反 $(\mathrm{COI})$ の開示 :

本論文発表内容に関連して開示すべき企業との利益 相反なし

\section{文献}

1) George JN, Nester CM: Syndromes of thrombotic microangiopathy. N Engl J Med 371: 654-666, 2014.

2）藤村吉博, 吉田瑶子, 範新萍, 宮田敏行：非典型溶血 性尿毒症症候群 (aHUS)。臨床血液 53: 351-359, 2014.

3）宮川義隆：ITP と TTP に対するリツキシマブ. 日本内 科学会雑誌 103: 1654-1659, 2014.

4) Scully M, McDonald V, Cavenagh J, Hunt BJ, Longair I, Cohen H, Machin SJ: A phase 2 study of the safety and efficacy of rituximab with plasma exchange in acute acquired thrombotic thrombocytopenic purpura. Blood 118: 17461753, 2011.

5) Scully M, Cohen H, Cavenagh J, Benjamin S, Starke R, Killick S, Mackie I, Machin SJ: Remission in acute refractory and relapsing thrombotic thrombocytopenic purpura following rituximab is associated with a reduction in $\mathrm{IgG}$ antibodies to ADAMTS-13. Br J Haematol 136: 451-461, 2007.

6) Scully M, Goodship T: How I treat thrombotic thrombocytopenic purpura and atypical haemolytic uraemic syndrome. $\mathrm{Br}$ J Haematol 164: 759-766, 2014.

7) Taylor CM, Machin S, Wigmore SJ, Goodship TH; working party from the Renal Association, the British Committee for Standards in Haematology and the British Transplantation Society: Clinical practice guidelines for the management of atypical haemolytic uraemic syndrome in the United Kingdom. Br J Haematol 148: 37-47, 2010.

8) Tsai HM: Untying the knot of thrombotic thrombocytopenic purpura and atypical hemolytic uremic syndrome. Am J Med 126: 200-209, 2013.

9) Noris M, Mescia F, Remuzzi G: STEC-HUS, atypical HUS and TTP are all diseases of complement activation. Nat Rev Nephrol 8: 622-633, 2012.

10) Campistol JM, Arias M, Ariceta G, Blasco M, Espinosa M, Grinyó JM, Praga M, Torra R, Vilalta R, Rodríguez de Córdoba S: An update for atypical haemolytic uraemic syndrome: diagnosis and treatment. A consensus document. Nefrologia 33: 27-45, 2013.

11）宮川義隆：TTP と非典型 HUS の最新治療. 医学のあゆ み 251: 149-156, 2014.

12) Cataland SR, Wu HM: How I treat: the clinical differentiation and initial treatment of adult patients with atypical hemolytic uremic syndrome. Blood 123: 2478-2484, 2014.

13) Cataland SR, Holers VM, Geyer S, Yang S, Wu HM: Bio- markers of terminal complement activation confirm the diagnosis of aHUS and differentiate aHUS from TTP. Blood 123: 3733-3738, 2014.

14) Noris M, Galbusera M, Gastoldi S, Macor P, Banterla F, Bresin E, Tripodo C, Bettoni S, Donadelli R, Valoti E, Tedesco F, Amore A, Coppo R, Ruggenenti P, Gotti E, Remuzzi G: Dynamics of complement activation in aHUS and how to monitor eculizumab therapy. Blood 124: 1715-1726, 2014.

15）非典型溶血性尿毒症症候群診断基準作成委員会：非典 型溶血性尿毒症症候群 診断基準。日本腎臓学会誌 55: 91-93, 2013.

16) Scully M, Hunt BJ, Benjamin S, Liesner R, Rose P, Peyvandi F, Cheung B, Machin SJ; British Committee for Standards in Haematology: Guidelines on the diagnosis and management of thrombotic thrombocytopenic purpura and other thrombotic microangiopathies. Br J Haematol 158: 323-335, 2012.

17) Coppo P, Schwarzinger M, Buffet M, Wynckel A, Clabault K, Presne C, Poullin P, Malot S, Vanhille P, Azoulay E, Galicier L, Lemiale V, Mira JP, Ridel C, Rondeau E, Pourrat J, Girault S, Bordessoule D, Saheb S, Ramakers M, Hamidou M, Vernant JP, Guidet B, Wolf M, Veyradier A; French Reference Center for Thrombotic Microangiopathies: Predictive features of severe acquired ADAMTS13 deficiency in idiopathic thrombotic microangiopathies: the French TMA reference center experience. PLoS ONE 5: e10208, 2010.

18) Noris M, Caprioli J, Bresin E, Mossali C, Pianetti G, Gamba S, Daina E, Fenili C, Castelletti F, Sorosina A, Piras R, Donadelli R, Maranta R, van der Meer I, Conway EM, Zipfel PF, Goodship TH, Remuzzi G: Relative role of genetic complement abnormalities in sporadic and familial aHUS and their impact on clinical phenotype. Clin J Am Soc Nephrol 5: 1844-1859, 2010.

19) Saland JM, Ruggenenti P, Remuzzi G; Consensus Study Group: Liver-kidney transplantation to cure atypical hemolytic uremic syndrome. J Am Soc Nephrol 20: 940-949, 2009.

20) Legendre CM, Licht C, Muus P, Greenbaum LA, Babu S, Bedrosian C, Bingham C, Cohen DJ, Delmas Y, Douglas K, Eitner F, Feldkamp T, Fouque D, Furman RR, Gaber O, Herthelius M, Hourmant M, Karpman D, Lebranchu Y, Mariat C, Menne J, Moulin B, Nürnberger J, Ogawa M, Remuzzi G, Richard T, Sberro-Soussan R, Severino B, Sheerin NS, Trivelli A, Zimmerhackl LB, Goodship T, Loirat C: Terminal complement inhibitor eculizumab in atypical hemolytic-uremic syndrome. N Engl J Med 368: 2169-2181, 2013.

21) Ardissino G, Testa S, Possenti I, Tel F, Paglialonga F, Salardi $\mathrm{S}$, Tedeschi S, Belingheri M, Cugno M: Discontinuation of eculizumab maintenance treatment for atypical hemolytic uremic syndrome: a report of 10 cases. Am J Kidney Dis 64: 633-637, 2014. 